\title{
Psychological Capital: A Positive Psychological Resource and Its Relationship with Creative Performance Behavior
}

\author{
Psikolojik Sermaye: Bir Pozitif Psikoloji Kaynağı ve Yaratıcı Performans \\ Davranışı ile İlişkisi
}

\section{Asst. Prof. Dr. Seçil Bal Taştan}

\begin{abstract}
Creative performance behavior and psychological capital concepts having theoretical roots of positive organizational behavior and positive psychological capital have been examined in a number of studies in literature for investigating high performance and innovative organizations. It is recognized that the employee creative performance behavior has been the investigated with its associations with several concepts including supportive managerial implementation, job characteristics, organizational climate and culture, personality factors. The present study has focused on the assumption regarding the relationship between psychological capital components of self-efficacy, hope, optimism and resilience with creative performance behavior. Based on the extant resources and conceptual rationale, it is expected that psychological capital variables could have significant explanatory power on employee creative performance behavior. With that respect, a research study was performed in a large size White Good Company in Turkey which has been indicated as an innovative and high performance organization by relevant research results. 165 first line and middle level white and blue collar employees have participated in the questionnaire survey. The data were analyzed through the use of SPSS and LISREL programmes. Each variable of the model was evaluated by Confirmatory Factor Analysis (CFA) methods. According to the results, it was revealed that
\end{abstract}

the total psychological capital and each of the psychological capital components had significant positive relationships with employee creative performance behavior. In addition, it was demonstrated that psychological capital components had significant effect on explaining creative performance behavior.

Keywords: Psychological Capital, Positive Psychology, Creativity, Creative Performance Behavior

\section{Öz}

Kuramsal köklerini pozitif örgütsel davranış ve pozitif psikoloji kuramlarından alan çalışanlarda yaratıcl performans ve psikolojik sermaye kavramları alan yazında yüksek performansl ve yenilikçi örgütleri inceleyen çok sayıda çalışmada ele alınmıştır. Konu ile ilgili alan yazında, çalışanlarda yaratıcı performans davranışlarının daha çok destekleyici yönetim uygulamaları, iş karakteristikleri, örgüt iklimi ve kültürü, kişilik özellikleri gibi kavramlar ile ilişkilendirilmekte olduğu görülmektedir. Bu çalışma, örgütlerde yaratıcllık ve pozitif psikolojik sermaye konuları çerçevesinde, öz yeterlilik, umut, iyimserlik ve dayaniklilk olarak belirlenmiş olan psikolojik sermaye değişkenlerinin çalışanlardaki yaratıcı performans davranışları ile ilişkili olabileceği varsayımı üzerinde odaklanmıştır.

Asst. Prof. Dr. Seçil Bal Taştan, Marmara University Faculty of Business Administration, secilbal@yahoo.com 
Konu ile ilgili mevcut kaynaklarm ve kuramsal gerekçelerin ışı̆̆ında, psikolojik sermaye değişkenlerinin yaratıcı performans davranışları üzerinde anlamlı bir açıklayıcı güce sahip olabileceği beklenmiştir. Bu doğrultuda, Türkiye'de Beyaz Eşya Sektöründe faaliyette bulunan ve yapılan çeşitli araştırmalara göre, yenilikçi ve yüksek performansl kurum olarak nitelendirilmiş olan büyük ölçekli bir firmada araştırma gerçekleştirilmiştir. Uygulanan anket çalışmasına 165 alt ve orta kademelerde çalışan mavi ve beyaz yakalı personel katılmıştır. Elde edilen veriler SPSS ve LISREL programları kullanılarak analize tabi tutulmuş, Doğrulayıcı Faktör Analizi (DFA) yöntemi ile değişkenlere ilişkin ölçümlemeler gerçekleştirilmiştir. Elde edilen sonuçlara göre, psikolojik sermaye bütün değişkeninin ve dört alt değişkeninin çalışanlarda yaratıcı performans davranışı ile pozitif ve anlaml ilişkilere sahip olduğu ve yaratıcı performans davranışını açıklamada anlamlı bir etkiye sahip olduğu belirlenmiştir.

Anahtar Kelimeler: Psikolojik Sermaye, Pozitif Psikoloji, Yaratıcılık, Yaratıcı Performans Davranışı

\section{Introduction}

In recent decades, employees' creative performance behavior and innovative behavior have been considered important human capital that contributes to a an organization's performance, competitive advantage and sustainability and creativity have been seen as successful implementation of novel and useful creative ideas offered by employees (Amabile, Conti, Coon, Lazenby and Herron, 1996, Amabile, 1998; Kor and Mahoney, 2000; Amabile, Barsage, Mueller and Staw, 2005; Gümüşlüoğlu and İlsev, 2009). Recently, scholars employing the positive psychology approach in creative performance research have emphasized the uniqueness of creative individuals as well as the effect of positive psychological states on motivational process and creative performance behavior (e.g., Kwang and Rodrigues, 2002; Luthans, Youssef, and Avolio, 2007; Sweetman, Luthans, Avey and Luthans, 2011; Mishra, Bhatnagar and Gupta, 2013). Until today, the theory and research on organizational behavior, positive psychology and creativity have been focused on the role of positive psychological capital (Avey, Lut- hans and Jensen, 2009; Peterson, Walumbwa, Byron, and Myrowitz, 2009; Sweetman et al., 2011; Hsu, Hou and Fan, 2011). However, it was recognized that the subject of whether individuals who have certain positive psychological traits (e.g., self-efficacy, hope, optimism, resilience) will actually exhibit creative performance behavior has been understudied.

Research into the determinants of creative performance has been extensively studied by various theorists and academics. The extant literature addresses two alternative and frequently used theories among several other approaches to identify the determinants of creative performance behavior. One of the theories has been developed by Amabile $(1996,1997)$ introducing "Componential Model of Creativity" for explaining cognitive, personality, motivational, and environmental factors relating with creative performance. The other theory "Investment Theory of Creativity" by Sternberg and Lubart (1991) explored resources including intellectual abilities, thinking styles, personality, motivation, and environment (Sternberg, 2006) for understanding the creative performance behavior. Both background theories have provided considerable insights for the present study. As such, the presumed association between the research variables of this study was emerged upon the prior conceptual and empirical knowledge obtained from the extensive literature and the hypothesized relationships were generated with the theoretical implications of the relevant theoretical roots and empirical evidences.

In sum, the present study aimed to investigate the relationship between components of psychological capital; -self-efficacy, hope, optimism, reliance- and employees' creative performance behaviors throughout a research applied in a Turkish White-Good Company setting.

\section{Literature Review and Hypotheses Development}

The present study begins by reviewing the literature through a preliminary survey upon the previous conceptual and empirical studies including the study variables. Thereafter, the study will present the discussions of the theoretical background and research hypotheses of the main constructs (creative performance behavior and psychological capital). 


\section{Positive Organizational Behavior}

A growing number of positive-oriented research of Positive Organizational Behavior (POB) has enabled the investigation of the wellbeing of individuals in particular to its relevance to workplace and contributed to the conceptualization of the approach (e.g., Seligman, 2002; Luthans, 2002a, 2002b; Luthans and Youssef, 2007; Luthans et al., 2007; İslamoğlu, 2010; Sweetman et al., 2012). POB is defined as "the study and application of positively oriented human resource strengths and psychological capacities that can be measured, developed, and effectively managed for performance improvement" (Luthans, 2002b, p.59). Positive psychology got its importance with the research studies and propositions of Seligman (2002) and his book "Authentic Happiness" in which he focused on strengths rather than weaknesses, health and vitality rather than illness and pathology of individuals at work. Seligman (2002) suggested that when individuals are engaged (absorbed in flow), perhaps they were investing, building psychological capital for future. Luthans, Luthans and Luthans (2004) argued that when applied to the workplace that "flow" could be restated in terms of personal and organizational goal alignment and job fit (p.46). They maintained that psychological capital was beyond human capital and social capital and basically reflected "who an individual is" in the workplace rather than what he/ she knows. Briefly, drawn from positive psychology, "positive organizational behavior" referred four positive psychological capacities of efficacy (confidence), hope, optimism, and resilience (Luthans et al., 2004, p.47) and these four states have also been used by Stajkovic (2003, p.5 and 2006, p.1208) in his core confidence factor for work motivation. It has been indicated that according to $\mathrm{POB}$ approach, such four capacities are measurable, open to development, and can be managed for more effective work performance (Luthans, 2002a; Luthans et al., 2004; Abbas and Raja, 2014).

The following part of the present study will briefly define these four states as they can be applied to work environments and contribute to positive psychological capital, in associations with a number of organizational and individual outcomes of increased performance, commitment, job satisfaction, creativity, innovative work behaviors and decreased intention to turnover, job stress etc.

\section{Psychological Capital As A Positive Psychological Resource}

Such an approach of POB has incorporated with many existing Organizational Behavior concepts from the domains of attitudes, personality, motivation, and leadership in both international and Turkish research studies (e.g., Seligman and Csikszentmihalyi, 2000; Schabracq, Winnubst and Cooper, 2003; Zajacova, Lynch and Espenshade, 2005; Atilla-Bal, 2008; Sutter, 2008; İslamoğlu, 2010; Sweetman et al., 2012). Especially, by being positive and measurable concepts, self-efficacy/ confidence, hope, optimism, subjective and work related well-being, employee wellness, and emotional intelligence have been included in POB (Luthans, 2002a) and in recent years these concepts have become main concern to organizational behavior and management scholars. To date, through growing theory-building and empirical research, Luthans and colleagues have identified the constructs of efficacy, hope, resilience, and optimism as best meeting the inclusion criteria for psychological capital as a positive psychological resources as described with POB (Luthans et al., 2007).

In this context, derived from POB thinking, psychological capital has emerged as a positive oriented higher order construct (Luthans, 2002a, 2002b; Luthans and Youssef, 2007) and the higher order psychological capital is defined as "an individual's positive psychological state of development”. Briefly, according to Luthans et al. (2007) psychological capital was characterized by having confidence (self-efficacy) to take on and put in the necessary effort to succeed at challenging tasks; making a positive attribution (optimism) about succeeding now and in the future; persevering toward goals and, when necessary, redirecting paths to goals (hope) in order to succeed; and sustaining and bouncing back and even beyond (resilience) to attain success" (p.3).

"Hope" has been indicated as the first component of core psychological capital and Snyder, Irving and Anderson (1991, p.287) have pioneered the definition of the concept as "a positive motivational state that is based on an interactively derived sense of successful agency (goal-directed energy) and pathways (planning to meet goals)". Other scholars also indicated that hope possesses the willpower to perform creatively and to creatively explore multiple pathways to 
reach the goals (Snyder, 2000; Larson and Luthans, 2006; Luthans et al., 2007). Snyder (1994) argued that hope increases the cognitive efforts towards goal attainment and Snyder et al. (1998) suggested that high hope individuals use goal directed thinking to move along a pathway and continuing to progress along.

"Optimism" has been indicated as the second positive resource capacity of psychological capital. Optimistic individuals relate negative events as external (not my fault), unstable (occurred this time only), and specific (this event only), while pessimists interpret the same events as internal, stable, and global (Seligman, 1998; Peterson, 2000; Abbas and Raja, 2014). Seligman (1998) mentioned that an optimist gives external attribution to negative events to consider external situations and other individuals responsible. Thus, such an external attribution avoids any reduction in optimist people's efforts even in difficult situations. Moreover, it was suggested that optimists feel that good things will happen leading to important cognitive and behavioral consequences (Avey, Patera and West, 2006).

"Self-efficacy" is described as a self-evaluation of one's competence to successfully execute a course of action necessary to reach desired outcomes (Bandura, 1986). Stajkovic and Luthans (1998) defined the concept as "the employee's conviction or confidence about his or her abilities to mobilize the motivation, cognitive resources or courses of action needed to successfully execute a specific task within a given context" (p.66). An extensive body of research has shown that self-efficacy is positively associated with work-related outcomes of job performance, creativity, and motivation. Deci and Ryan (2000) addressed that employees high on efficacy are high on intrinsic motivation and consider themselves to be competent. Bandura and Locke (2003) implied that self-efficacy had a strong positive relationship with work-related performance. It has been argued that individuals with high self-efficacy continue to have intrinsic motivation even when faced with difficult situations, and believe that they can deal successfully with difficult situation (e.g., Tierney and Farmer, 2002; Gong, Huang and Farh, 2009; Nielsen, Yarker, Randall and Munir, 2009; Gupta and Singh, 2014).

"Resilience" is the fourth component of psychological capital and it was indicated that resilient individuals have the ability to positively cope and adapt during risk and adversity (Masten and Reed, 2002).
Luthans (2002a) described resilience as the positive psychological capacity to bounce back from uncertainty, conflict, failure or even positive changes and increased responsibilities (p.702). Bandura and Locke (2003, p. 92) underlined that resilient belief provides the necessary staying power to the individual when he/she faces failures and problems and discouraging situations. Coutu (2002) and Tugade and Fredrickson (2004) added that resilience helps individuals to become flexible and adapt themselves during highly changing and uncertain situations since they can overcome difficult situations.

In accordance with previous readings on the conceptualization and operationalization of psychological capital construct, in this study, each component of the construct has been regarded as the potential antecedent of individual creative performance behaviors. In addition, it was attempted to evaluate the factorial structure of the psychological capital throughout the survey of the present study within the Turkish cultural context. Therefore, initially, the following hypothesis was generated.

Hypothesis 1: Psychological capital is a four-dimensional construct described by self-efficacy, hope, optimism and resilience.

Furthermore, as previous literature demonstrated, Positive Psychological Capital has been found to be related to various employee work attitudes and behaviors such as job satisfaction (Luthans, Avolio, Avey and Norman, 2007; Erkuş and Fındıkl1, 2013), organizational commitment (Larson and Luthans, 2006), job stress (Avey et al., 2009; Abbas and Raja, 2014), intention to turnover (Avey, Luthans and Youssef, 2010; Erkuş and Findıkl1, 2013), cynicism (Avey, Wernsing and Luthans, 2008), absenteeism (Avey et al., 2006), job performance (Luthans, Norman, Avolio, and Avey, 2008; Luthans, Avolio, Avey and Norman, 2007; Akdoğan and Polatçı, 2013; Erkuş and Findıkl1, 2013), innovative performance (Abbas and Raja, 2014), innovative work behaviors (Mishra et al., 2013), employee creativity (Battal, 2013), creative performance (Sweetman et al., 2011). For all that, how the employees become involved in creative performance behaviors remains indefinite and needs further research. We suggest that the studies that examine the involvement of positive psychological capital components in creative performance behaviors are still inadequate. Therefore, the objective of the 
present study is to fill the gap in literature through the examination of the relationships between positive psychological capital components and employee creative performance behaviors.

Thus, the next section will briefly present discussions on the outcomes of positive psychological capital and more particularly, will put an emphasis on psychological capital for creative performance behaviors in the organizations. We posit that positive psychological capital influence employee creative performance behaviors.

\section{Creative Performance Behaviors}

The extant literature provides several definitions of creativity, creative performance and innovation. A widely accepted definition of creativity was put forth with the statement of "the production of novel and useful ideas, and innovation is the successful implementation of creative ideas within an organization" (Amabile, 1998, p.78; Amabile et al., 1996, p.1156). Thus, creativity has been undertaken at the individual level and innovation has been argued out at the organizational level (e.g., Staw, 1990; Amabile et al., 1996; Oldham and Cummings, 1996; Gümüşlüoğlu and İlsev, 2009). Amabile (1998, p.78) viewed creativity as "the production of novel and useful ideas by an individual or small group of individuals working together". Briefly, creativity in organizations has been described as the "process of coming up with new ideas for changing products, services, and processes to better achieve the organization's goals" (Amabile et al., 2005).

Creative performance then refers to products, ideas, and so forth produced at the individual level, whereas innovation refers to the successful implementation of these products at the organizational level (Oldham and Cummings, 1996, p. 609). With that recognition, Sweetman et al. (2011) have pinpointed that creative performance "involves the behaviors through which an individual's creative potential is manifest (p.7)". Thus, following the conceptualization of Amabile (1998), Staw (1990) and Oldham and Cummings (1996), in our definition we consider the distinction between creative performance behaviors and organizational innovation. Therefore, in the present study, we focus on the generation of creative performance outcomes by employees, not on the implementation of these outcomes.
A number of researchers have found creative performance to be a source of innovation within organizations and as something that is needed for a variety of jobs across a variety of organizations (e.g., Sternberg, 1985; Amabile et al., 1996; Shalley, Gilson and Blum, 2000; DiLiello and Houghton, 2006; Gümüşlüoğlu and İlsev, 2009; Tang and Chang, 2010; Sweetman et al., 2012). A long with its suggested importance for both employees and organizations, creative performance has been studied with particular attention to its antecedents and consequences. In his earlier study of "On the Modelling of Creative Behavior", Cohen (1981) provided implications regarding the positive individual and organizational outcomes of creative behaviors. In their book named as High-performance Work Organizations, Kirkman, Lowe and Young (1999) underlined the crucial importance of individual creative performance for enhancing high performance and success in the organizations. Several other studies have confirmed the positive impacts of creativity and creative performance behaviors on organizational performance (e.g., Mostafa, 2005; Mishra and Singh, 2010; Bratnicka, 2013).

Further, a body of research studies on creative performance behavior provided theoretical background and implications for understanding the potential determinants and antecedents of the construct. $\mathrm{W}$ i t $\mathrm{h}$ his theoretical work, Amabile (1988, 1996, 1997) introduced "Componential Model of Creativity", as a general framework which described relevant environmental factors that can influence employee creativity in positive or negative directions. The subsequent studies (e.g. Redmond, Mumford and Teach, 1993; Amabile et al., 1996; Oldham and Cummings, 1996; Simonton, 2000; Eren and Gündüz, 2002; Kahai, Sosik and Avolio, 2003; Ceylan and Savi, 2003; Shalley, Zhou and Oldham, 2004; Yahyagil, 2005; Kaufman, Cole and Baer, 2009; Sweetman et al., 2011) have reviewed Amabile's (1997) componential model of creativity for understanding how cognitive, personality, motivational, and societal factors effect creative performance. In the "Investment Theory of Creativity" by Sternberg and Lubart (1991, p.3), it was indicated that creativity required a confluence of six distinct but interrelated resources: intellectual abilities, knowledge, styles of thinking, personality, motivation, and environment (Sternberg, 2006, p.88).

In accordance with the relevant background theories of creative performance, subsequent implications and 
findings regarding the personal, motivational, contextual and environmental factors were derived from the literature (e.g., Woodman, Sawyer and Griffin, 1993; Oldham and Cummings, 1996; Gabora, 2002; Shalley and Gilson, 2004; Amabile, Schatzel, Moneta and Kramer, 2004; Choi, 2004; Yahyagil, 2005; Gümüşlüoğlu and İlsev, 2009; Tang and Chang, 2010). A widely cited article of Oldham and Cummings (1996) examined the independent and joint contributions of employees' creativity-relevant personal characteristics and characteristics of the organizational context and provided conceptual discussion on the personal and psychological indicators of employee creativity. Cropley (1999) emphasized the significance of individual cognitions for creative performance. Moreover, Amabile et al. (1996) ensured a broad contribution to the understanding of work environment's impact on creativity. Other empirical studies supported the links of leader behaviors (e.g., Redmond et al., 1993, Tierney, Farmer and Graen, 1999; Jung, 2001; Kahai, Sosik and Avolio, 2003; Amabile, Schatzel, Moneta and Kramer, 2004) and work environment factors (e.g., Eren and Gündüz, 2002; Ceylan and Savi, 2003; Perry-Smith and Shalley, 2003; Wong and Pang, 2003; Tekin 2008) to creative performance. Perry-Smith and Shalley (2003) explained creativity by social aspects with a static and dynamic causal network perspective. Mumford (2000) addressed a variety of strategies to manage creative people and Shalley and Smith (2001) demonstrated the significant effects of social-psychological factors on creative performance. Specifically, Zhou and George (2001) focused on how job dissatisfaction leads to creativity at work. Furthermore, Barron and Harrington (1981) pioneered the examination of intrapersonal and personality attributes of creativity. In addition, previous studies examined several psychological work environment perceptions that influence creative performance in organizations such as social support and psychological empowerment (Scott and Bruce, 1994) and psychological empowerment (Deci, Connell and Ryan, 1989). In their study, Zhou and George (2003) indicated the role of emotional intelligence on employee creativity. Feedback valence, feedback style, task autonomy, and achievement orientation were also revealed as having interactive effects on creative performance (Zhou, 2003).

\section{The Relationship Between Psychological Capital and Creative Performance Behaviors}

In accordance with our study's objective, Sweetman et al.s (2011) findings were remarkable which demonstrated the significant impacts of psychological capital dimensions on creativity performance. Despite the strong conceptual background and research on the personal-environmental antecedents of creative performance, relatively less attention has been devoted to creative performance as it relates to an individual's psychological resources such hope, selfefficacy, optimism and resilience as identified with positive psychological capital concept. In the creativity and psychological capital literature, there is some support for their positive relationship (e.g., Ambrose and Kulik, 1999; Mishra et al., 2013; Abbas and Raja, 2014; Battal, 2013). Therefore, we focus our attention to the investigation of such motivational mechanisms for creative performance which we assume are embodied in the positive psychological resources of hope, self- efficacy, optimism, and resiliency, and the overall construct of psychological capital.

Considerable amount of research has focused on dispositional factors that may stimulate creative performance behaviors at the workplace. There are certain personality factors that have been found to be related to creative behaviors at the workplace including creative self-efficacy (Tierney and Farmer, 2002; Hsu et al., 2011), emotional creativity (Averill, 1999) and positive affect (Isen, Daubman and Nowicki, 1987). Recently, few studies attempted to explore the relationship between positive psychological resources and creative performance; however, these studies mostly linked the resources with creativity related outcomes separately. For example, Hsu et al. (2011) investigated self-efficacy with innovative behavior and similarly, Tierney and Farmer (2002) investigated the relationship between efficacy and creative performance. In addition, Rego, Machado, Leal and Cunha (2009) examined the relationship between hope and employee creativity and Rego, Sousa, Marques and Cunha (2012) investigated the relationship between optimism and creativity.

The research findings have revealed that hopeful employees highly engaged creative behaviors in the organizations (Luthans et al., 2007) since hopeful in- 
dividuals tended to take risks and look for alternatives when faced with difficulties (Snyder, 1994, 2002). Moreover, Carmeli, Meitar and Weisberg (2006) have indicated that optimism was essential in the first stage of the creative and innovative processes since optimism helped an individual to concentrate on positive aspect of the task. As further, recent studies showed positive association between resilient employees and job performance (e.g., see Luthans and Avolio et al., 2007). In a study of Youssef and Luthans (2007), it was revealed that higher resilient employees exhibited higher job satisfaction, organizational commitment, and work happiness. Such kind of a finding could enhance the researchers to turn their attention to investigate the impact of resilience as one of a psychological capital component on employee creative performance. Abbas and Raja (2014) proposed that psychological capital was positively and significantly related to innovative work behavior by building their model on Avey, Luthans and Jensen's (2009) implications. Avey et al. (2009, p.685) have argued that hope, optimism, self-efficacy and resilience which together formed a higher-order construct of psychological capital provided the organizations with a new human resource development approach to help employees build the critical resources they needed.

Moreover, Mishra et al's (2013) research study supported the role of psychological capital in the relationship between work-to-family enrichment, familyto-work enrichment and innovative work behavior. Sweetman et al.s (2011) study provided remarkable empirical findings related to the relationship between positive psychological capital and creative performance. Drawing from a large $(\mathrm{N}=899)$ and heterogeneous sample of working adults, their study examined psychological capital and its components (efficacy, hope, optimism, and resilience) as predictors of creative performance and found that overall psychological capital predicted creative performance over and above each of the four components (Sweetman et al., 2011). Further, in a Turkish study, the effect of the psychological capital was revealed as effecting creativity (Battal, 2013). Gupta and Singh (2014) conducted a research in the Indian research and development context and found that psychological capital had a mediating effect on the relationship between leadership and creative performance behaviors.

In sum, although the extant literature provides a number of empirical evidence regarding the antecedents and outcomes of psychological capital, to the knowledge of author, still there is a gap within the published literature about the argument on the impact of psychological capital components on creative performance behavior. Hence, based on the previous theoretical roots and literature evidences, it is expected that there will be a relationship between four facets of psychological capital- i.e. self-efficacy, hope, optimism and resilience with the creative performance behaviors of employees. In accordance with this description, the following hypotheses are generated and the proposed theoretical research model is presented with Figure 1.

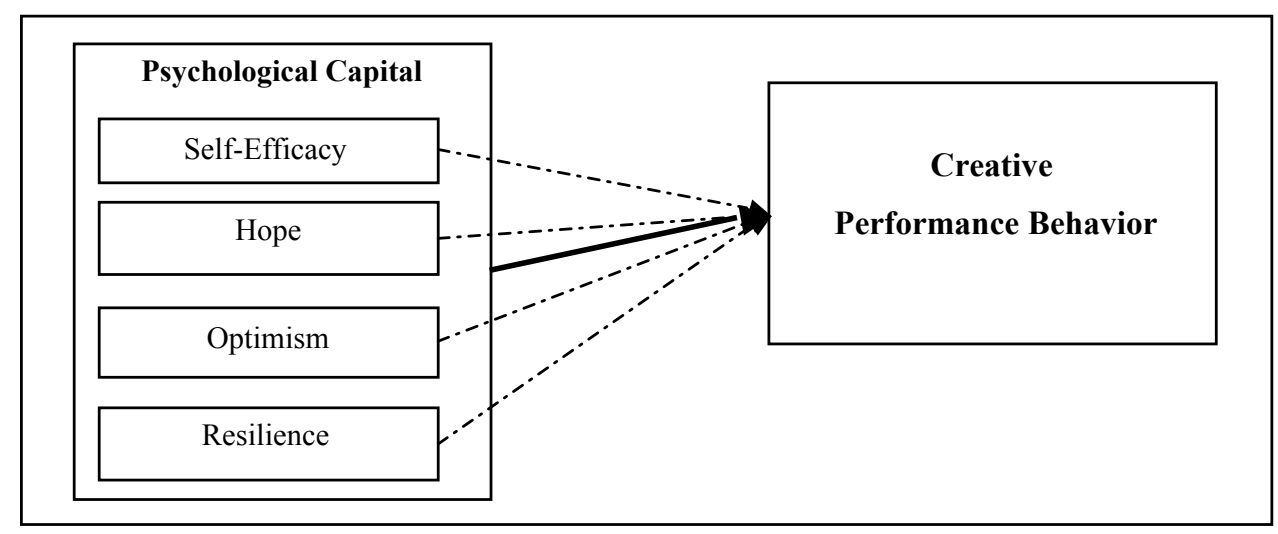

Figure 1. The Theoretical Research Model 
Hypothesis 2: Psychological capital is positively and significantly related to creative performance behavior.

Hypothesis 2a: Self-efficacy is positively and significantly related to creative performance behavior.

Hypothesis 2b: Hope is positively and significantly related to creative performance behavior.

Hypothesis 2c: Optimism is positively and significantly related to creative performance behavior.

Hypothesis 2d: Resilience is positively and significantly related to creative performance behavior.

\section{Methodology}

The first section has made up the literature review and theoretical part of the study, thus creating a conceptual framework for the empirical research, which is presented in the second section. Initially, to make related methodological assumptions, a model approach has been presented for understanding creative performance behavior and psychological capital dimensions. Then, the methodology of empirical research is presented with the main focus on the research model, hypotheses, sample identification, procedure, variable measurement, and data analysis. The results are thoroughly explained and the relations between the dimensions of psychological capital and creative performance behavior are interpreted. Thus, the section is concluded with a discussion and interpretation of the research findings and test of hypotheses.

\section{Sample and Procedures}

In total, 165 employees from a company (one of the biggest Turkish white-goods companies in Turkey) operating in white goods sector in Turkey participated in the present study. The company is comprised of 29 companies operating in manufacturing, software and technology development, marketing, and distribution fields in the consumer electronics, household appliances, multimedia communication, LED lighting, and defense industries in Turkey. The company has been operating under one of the leading Holding Groups in Turkey, and has been involved in its production and export activities with a large market share. The R\&D, Technology and Manufacturing employees of the company were asked to engage in developing creative services, products, or techniques for the company. Therefore, the target sample group of employees was suggested to be appropriate for the research objective and research variables of the present study. The respondents' perceptions regarding their self-reported creative performance behavior and psychological capital were inquired by utilizing paper-based questionnaires. Data were obtained from the respondents approximately over four months (February-May, 2014). Throughout a convenience sampling method, 165 respondents working in four different departments -i.e., R\&D, manufacturing, design, and technology -laboratory- completed the questionnaires $(n=165)$, and the response rate was $75 \%$ since the total number of the questionnaires delivered were $220(=165 / 220)$. The sample size was identified as approximately 612 white and blue color employees (data obtained from 2012 report of the company). Therefore, it is suggested that our sample had a representative power of the population $95 \%$ confidence interval. The results of the descriptive analyses showed that the majority of the respondents were male $(81,4 \%)$; on average, they had completed university level education (78,3\%), and their average job tenure was 6.89 years. Among 165 employees, 51 were working in technology services department, 66 were working in manufacturing department, and the remaining 48 were holding jobs in R\&D department.

\section{Measures}

The research instruments of the present study consisted of the psychological capital and creative performance behavior scales. The employees rated their perceptions of each item using a six-point Likert scale, ranging from 1 ("strongly disagree") to 6 ("strongly agree"). Each scale was originally in English and then translated into Turkish by the researcher.

\section{Measurement of the Dependent Variable: Creative Performance Behavior}

In this study, creative performance behavior was measured via self-reported measure which was found appropriate because it is aimed to obtain data about how the employees evaluate the tasks they perform at work that make them creative. Such kind of a selfreport method was utilized in previous studies for the evaluation of employee creative performance behavior (e.g., Mishra and Singh, 2010). Sweetman et al. (2011) have performed a questionnaire survey in 
order to measure the creative performance and their sample included working adults from a wide cross section of organizations, levels and jobs. Due to their meaningful and confirmatory results, we have adopted the self-reporting method in the present study.

Since we considered the definition of Amabile (1998) for creativity as "the production of novel and useful ideas" (p.126); we adopted the 13-item scale of Zhou and George (2001) which was developed based on the creativity conceptualization of Amabile (1998). It has been recognized that a number of creative performance studies adopted that definition. In a recent research study, Tan and Chang (2010) have utilized the scale and found the Cronbach's Alpha value of 0,94.

In the present study, the 13 item scale was averaged for an overall score. The sample items included "I suggests new ways to achieve goals or objectives" and "I develop adequate plans and schedules for the implementation of new ideas". Cronbach's Alphas for this scale was yielded as 0,91 in our research setting which was higher than the acceptable level of 0,60 (Şencan, 2005). The results of the confirmatory factor analysis (CFA) showed that the fit index of the scale was acceptable $\left(\mathrm{x}^{2} / \mathrm{df}=2.23, \mathrm{RMSA}=.002\right.$, SRMR $=.03$, CFI $=.920)$ (Çokluk, Şekercioğlu and Büyüköztürk, 2010).

\section{Measurement of the İndependent Variable: Psychological Capital}

Psychological capital was measured using the 24 item Psychological Capital Questionnaire (PCQ) developed by Luthans et al. (2007, pp. 237-238). The scale was derived from the permission free access website of www.mindgarden.com directly and the items were translated to Turkish by the researcher. The relevant scale was validated by Luthans et al. (2007) for construct validity analysis and was used in subsequent studies (e.g., Avey, Wernsing and Luthans, 2008; Avey et al., 2009; Sweetman et al., 2011). In a recent study the reliability for the PCQ was revelaed as $\alpha=0.93$.

The PCQ contained six items for each of the four components of self-efficacy, hope, optimism, and resilience. Items are measured on a 6-point Likert scale.
The sample items included "When things are uncertain for me at work, I usually expect the best"; "Right now I see myself as being pretty successful at work"; "I usually take stressful things at work in stride". In the present study, the reliability for the PCQ was $\alpha=$ 0.94 . The results of the confirmatory factor analysis showed that the fit index of the scale was acceptable $\left(\mathrm{x}^{2} / \mathrm{df}=2.29, \mathrm{RMSA}=.08, \mathrm{SRMR}=.04, \mathrm{CFI}=.940\right)$ (Çokluk et al., 2010). According to the results of confirmatory factor analysis, each item of the psychological capital scale loaded on its principal component and each of the four components is fitted to the overall latent psychological capital construct. Such kind of a condition showed that psychological capital is considered a second order factor and is the shared variance of the components of self-efficacy, hope, optimism and resilience according to the implications of Law, Wong and Mobley, 1998. This result supported "hypothesis 1 " which indicated that psychological capital was a four-dimensional construct described by self-efficacy, hope, optimism and resilience. As such, these results were consistent with the previous works' results in terms of the validity of the scale (e.g., Luthans, Avolio et al., 2007; Sweetman et al., 2011).

\section{Results}

In the first stage, preliminary statistical analysis was performed for the evaluation of the means, standard deviations, and inter-correlations of all variables in the study. The mean, standard deviation and correlations among variables are presented with Table 1 . The mean values showed that self-efficacy component yielded highest mean value $(X=4,68)$ and optimism has the lowest mean value $(X=4,09)$. The dependent variable of the study has yielded a mean value of 4,44 .

In the second stage, for testing the hypotheses, Pearson Correlation Analysis was conducted with all the variables of the research model (Table 1). The results of the correlation analysis demonstrated that all components of psychological capital were positively correlated to employee creative performance behavior. These findings supported the "second hypothesis" of the study which was: "Psychological capital is positively and significantly related to creative performance 
Table 1. Mean Values, Standard Deviations and Inter-correlations among Variables

\begin{tabular}{|c|c|c|c|c|c|c|c|c|}
\hline & Mean & S.D. & 1 & 2 & 3 & 4 & 5 & 6 \\
\hline 1.Self-Efficacy & 4,68 & 83 & $(, 94)$ & & & & & \\
\hline 2.Hope & 4,53 &, 79 &, 29 & $(, 93)$ & & & & \\
\hline 3.Optimism & 4,09 &, 75 &, 53 & ,27 & $(, 89)$ & & & \\
\hline 4.Resilience & 4,33 & ,68 & ,26 &, 42 &, 44 & $(, 92)$ & & \\
\hline 5.Psychological & 4,47 & ,62 & ,46 &, 36 &, 38 &, 28 & $(, 94)$ & \\
\hline \multicolumn{9}{|l|}{ Capital (Total) } \\
\hline 6.Creative & 4,44 & 2,22 &, 55 & ,49 &, 38 & ,48 &, 51 & $(, 91)$ \\
\hline \multicolumn{9}{|l|}{ Performance } \\
\hline Behavior (Total) & & & & & & & & \\
\hline
\end{tabular}

Note: Correlation is significant at the 0,01 level (2-tailed). All the variables are scored on a 1 to 6 point scale; $n=165$. Figures in parentheses are reliabilities.

behavior" $(\mathrm{r}=, 51 ; \mathrm{p}<.01)$.

As it can be seen in Table 1, the "Pearson Correlation $r$ values" between each of the psychological components and the creative performance behavior construct varied between 0,38-0,55 which indicated moderate level correlations. The results showed that "self-efficacy" component of psychological capital had moderate positive significant correlation $(\mathrm{r}=0,55$; $\mathrm{p}<.01)$ and "hope" component had moderate positive significant correlation with creative performance behavior $(\mathrm{r}=0,49 ; \mathrm{p}<.01)$. Similarly, the "optimism" $(\mathrm{r}=0,38 ; \mathrm{p}<.01)$ and "resilience" $(\mathrm{r}=0,48 ; \mathrm{p}<.01)$ components had moderate positive correlations with creative performance behavior. Thus, the sub hypotheses of the "second hypothesis" (H2a, H2b, H2c, H2d) of the study were confirmed.

\section{Regression Analysis}

According to the correlation analysis results, no multicollinearity has been found among the psycholo- gical capital components, thus, multiple regression analysis could be conducted with these four components in order to see their statistical effects on the dependent variable of creative performance behavior. It is found necessary to test how much of the variance in the dependent variable is explained when all four independent variables are theorized to influence it. Therefore, since the research variables of the study were measured on an interval scale and there was more than one independent variable, multiple regression analysis could be performed (e.g., Çokluk et al., 2010; Sipahi, Yurtkoru and Çinko, 2012). In order to analyze how the psychological capital components significantly explain the variance in the creative performance behavior, linear regression analyses were conducted in order to see their contribution to the dependent variable. When creative performance behavior was the dependent variable with the independent variables of self-efficacy, hope, optimism and resilience, the regression equation of $Y 1=\beta 0+\beta 1 X 1+$ $ß 2 \mathrm{X} 2+ß 3 \mathrm{X} 3+ß 4 \mathrm{X} 4$ could be used (Y1 indicated the

Table 2. Model Summary of Regression Analysis

\begin{tabular}{|c|c|c|c|c|}
\hline Model & $\mathbf{R}$ & R Square & $\begin{array}{l}\text { Adjusted } \\
\text { R Square }\end{array}$ & $\begin{array}{l}\text { Std. Error of the } \\
\text { Estimate }\end{array}$ \\
\hline 1 & ,686(a) &, 526 &, 608 & ,47375 \\
\hline \multicolumn{5}{|c|}{ Predictors: (Constant), Self-Efficacy, Hope, Optimism, Resilience } \\
\hline
\end{tabular}


Table 3. Regression Analysis of Psychological Capital and Creative Performance Behavior

\begin{tabular}{|c|c|c|c|c|c|c|}
\hline Model & & $\begin{array}{l}\text { Sum of } \\
\text { Squares }\end{array}$ & df & Mean Square & $\mathbf{F}$ & Sig. \\
\hline \multirow[t]{3}{*}{1} & Regression & 71,603 & 11 & 6,855 & 42,641 &, $000(a)$ \\
\hline & Residual & 43,105 & 154 & 288 & & \\
\hline & Total & 114,708 & 165 & & & \\
\hline
\end{tabular}

Table 4. Summary Results of Coefficients of Regression Analysis

\begin{tabular}{|c|c|c|c|}
\hline \multicolumn{4}{|c|}{ Dependent Variable: Creative performance behavior } \\
\hline Independent Variables & Beta & t Value & P Value \\
\hline Constant & & 1,885 & 0,055 \\
\hline Self-Efficacy & 0,353 & 3,747 & 0,000 \\
\hline Hope & 0,326 & 2,295 & 0,020 \\
\hline Optimism & 0,341 & 4,233 & 0,000 \\
\hline Resilience & 0,253 & 4,055 & 0,000 \\
\hline \multicolumn{4}{|c|}{$\mathrm{R}=0,686 ; \mathrm{R}^{2}=0,526 ; \mathrm{F}$ Value $=42,641 ; \mathrm{p}<0,05$} \\
\hline
\end{tabular}

creative performance behavior and Xi's indicated the independent variables).

According to the implications of above tables (Table 2 , Table 3, Table 4), the regression results indicated that the independent variables jointly explained 52,6 $\%$ of the variance in the dependent variable of creative performance behavior $\left(\mathrm{R}^{2}=, 526 ; \mathrm{F}=42,641 ; \mathrm{p}<0\right.$, $05)$. The results revealed that self-efficacy $(\beta=, 353$, $\mathrm{p}<.05)$, hope $(\beta=, 326, \mathrm{p}<.05)$, optimism $(\beta=, 341, \mathrm{p}<$
$.05)$, and resilience $(\beta=, 253, \mathrm{p}<.05)$ were significantly effecting employees' creative performance behaviors. It can be argued from the results that the component which was labeled as self-efficacy was found to be the most influential factor on creative performance behavior. Among the components of the psychological capital, resilience was found to be the lower contributor towards employee creative performance behavior.

In sum, upon the findings of the regression analysis,

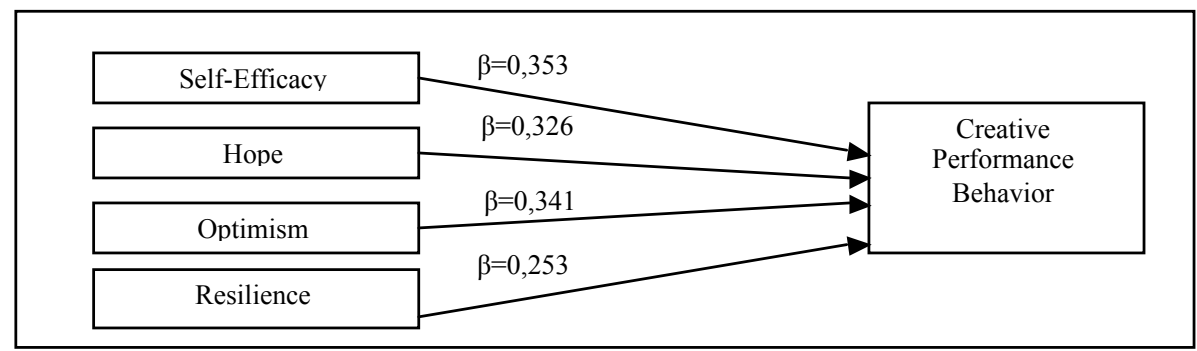

Figure 2. The Final Research Model after Multiple Regressions 
the final model of the research variables is presented with Figure 2.

\section{Conclusion and Discussion}

The purpose of this study was to examine the relationship between specific positive psychological resources (i.e., efficacy, hope, optimism, and resiliency), and their overall level of psychological capital, with creative performance behaviors of the working individuals in several departments of a high performance and innovative white-good company in Turkey.

The results of the research study have supported all the study hypotheses, i.e., there was a significant positive relationship between all the components of psychological capital individually and as an overall construct. In addition, the mean values demonstrated that self-efficacy component had the highest mean value and optimism had the lowest mean value, while the creative performance behavior core construct had a mean value of 4,44 . The mean values showed that the individuals who participated the survey have scored high on both psychological capital and creative performance behavior constructs. Moreover, the results of the correlation analysis demonstrated that all components of psychological capital were positively correlated to employee creative performance behavior. The Pearson Correlation values between each of the psychological components and the creative performance behavior construct were yielded on moderate levels. Therefore, the sub hypotheses which predicted positive significant relationships between the psychological capital components (i.e., efficacy, hope, optimism, and resiliency) and creative performance behavior were also supported. In addition, the regression analyses findings also demonstrated that psychological capital is a contributing core construct towards creative performance behavior. Briefly, it was demonstrated that psychological capital components, namely self-efficacy, hope, optimism and resilience could affect creative performance behavior.

Consequently, these results were consistent with prior empirical findings. Sweetman et al. (2011) have also found that each of the components of psychological capital was positively related to creative performance. Although the creative performance variable was measured with a different instrument, our results show consistency with their findings (Sweetman et al., 2011, p.17). Similarly, in the study of Hsu et al. (2011), the results showed that when employees' self-efficacy was high, employees with greater optimism exhibited greater innovative behavior at work. Therefore, our results in terms of the effects of self-efficacy and optimism on creative performance could be consistent with their study findings (Hsu et al., 2011, p.264). In addition, the recent study of Gupta and Singh (2014) which was conducted among Indian research and development context has demonstrated that psychological capital components and employee creative performance behaviors were positively and significantly related. Thus, our results could support their previous work's findings (Gupta and Singh, 2014, p.1387). Moreover, the results of the present study are also congruent with the findings of an earlier study which was conducted on the academicians working in Turkish Universities revealing that psychological capital positively impacted individual creativity (Battal, 2013, p.57).

As part of a concluding remark for the present study, it is suggested that each of the psychological capital components are central to accomplishments of employees work tasks and especially to their creative performance behaviors. Such a core value of psychological capital is also suggested to be vital for the employee accomplishments working in technological or industrial innovative organizations. Due to that prescribed importance of both psychological capital and creative performance, this study identified important psychological capital components that may influence employees' creative performance behaviors a Turkish White-Good Company context. Upon the detailed theory built and empirical analysis results, this study may yield specific suggestions for leaders/ managers/supervisors of employees whose job involves significant creative performance behaviors and creative problem solving skills. In addition, embedded in the Turkish cultural context, the results of the present study may provide important insights to researchers interested in studying psychological capital and its influence on employee creative performance behavior in the Turkish context. It is noted that any support from the organization for enhancing employees' self-efficacy, hope, optimism, and resilience may influence the goal-setting and cognitive processing of employees (see Gist and Mitchell, 1992, p.185; Hsu et al., 2011, p.267). It is implicated that employees will feel more confident, optimistic and flexible in facing situations and coping with uncertainties; thus, they will be likely to engage in creative performance be- 
haviors more due to the support motivating them to face challenges, to take risk, and to increase their capabilities in accomplishing their works.

\section{Limitations and Recommendations}

This study offers suggestions for future research as it had several limitations. At first, we address the problem of general applicability since the findings of this study may not apply to a situation in which employees do routine tasks and jobs that require no creativity or innovative idea. Besides, the findings may not apply to the contexts in which the employees do not interact with customers. Because this study was conducted in a setting facilitating technology, $R \& D$, and manufacturing activities, where all employees were adopting new ideas and solutions for their departments; the findings may not be applicable to a setting which is composed of employees doing routine tasks with less engagement of creative processes. Moreover, it is explicit that a research study involving the relevant variables would provide better and more representative results when applied in a larger sample of the population. As such, we suggest future studies to perform such kind of empirical research study within larger samples and broader industries. In addition, cross-cultural research studies could be attempted in order to provide findings about the cultural influences on the relevant variables.

The second limitation of the study is the use of a selfreported measurement of creative performance behavior which may cause a common method bias (Hammond, Neff, Farr, Schwall and Zhao, 2011, p.103). To solve this limitation, the further studies may use supervisor-reported (see Tang and Chang, 2010, p.873) or multiple reporting methods for the evaluation of employee creative performance behavior.

The third limitation is the lack of the test of contingent variables' effects on the study variables. The predicted relationship between psychological capital and creative performance behavior could be influenced by various contingent variables, such as dispositional variables, personal characteristics, personality factors, positive/negative mood, job characteristics and so forth. Therefore, it is suggested that further studies should examine the study variables with the inclusion of other contingent and/or contextual variables.

Furthermore, because scarce conclusion was reached on the relationships among self-efficacy, optimism, hope, resilience and employee creative performance behavior, we suggest that future researchers should conduct a meta-analysis. Although a large amount of prior studies based on positive psychology theory found a positive relationship between self-efficacy and employee creativity, there are also some studies which revealed a negative relationship between self-efficacy and performance related outcomes (see Vancouver, Thompson, Tischner and Putka, 2002, p.511; Bandura and Locke, 2003, p.88; Moores and Chang, 2009, p.72). Therefore, it is found necessary to go through the investigation of the self-efficacy-performance related outcomes association in future studies. Finally, it is suggested that the uncovered knowledge about how the relationship between self-efficacy and employee performance outcomes manifests should be clarified in order to better understand how that relationship accrues, whether self-efficacy impacts performance outcomes or visa-versa.

\section{References}

Abbas, M., Raja, U. (2014). Impact of perceived organizational politics on supervisory-rated innovative performance and job stress: evidence from Pakistan. Journal of Advanced Management Science, 2(2), 1-34.

Akdoğan A.A., Polatçi S., (2013). Psikolojik sermayenin performans üzerindeki etkisinde iş aile yayılımı ve psikolojik iyi oluşun etkisi. Atatürk University Social Sciences Institute Journal, 17, 273-293,

Amabile, T. M. (1988). A Model of Creativity and Innovation in Organizations. In B. M. Staw \& L. L. Cummings (Eds.), Research in organizational behaviour (vol. 10, pp. 123-167), Greenwich: JAI Press.

Amabile, T. M. (1996). Creativity in Context. Boulder, Colo.: Westview Press.

Amabile, T. M. (1997). Entrepreneurial creativity through motivational synergy. The Journal of Creative Behavior, 31(1), 18-26.

Amabile, T. M. (1998). How to kill creativity (pp. 7787). Harvard Business School Publishing.

Amabile, T. M., Barsage, S. G., Mueller, J. S., \& Staw, B. M. (2005). Affect and creativity at work. Administrative Science Quarterly, 50, 350-367. 
Amabile, T. M., Conti, R., Coon, H., Lazenby, J., \& Herron, M. (1996). Assessing the work environment for creativity. Academy of Managemen Journal, 39(5), 1154-1184.

Amabile, T. M., Schatzel, E. A., Moneta, G. B., \& Kramer, S. J. (2004). Leader behaviors and the work environment for creativity: Perceived leader support. The Leadership Quarterly, 15(1), 5-32.

Ambrose, M. L., Kulik, C. T. (1999). Old friends, new faces: Motivation research in the 1990s. Journal of Management, 25(3), 231-292.

Atilla-Bal, E. (2008). Self-efficacy, contextual factors and well-being: The impact of work engagement. Unpublished Doctorate Dissertation, Social Sciences Institute, Department of Organizational Behavior, Marmara University, Istanbul, Turkey.

Averill, J. R. (1999). Individual differences in emotional creativity: Structure and correlates. Journal of personality, 67(2), 331-371.

Avey, J. B., Luthans, F., Jensen, S. M. (2009). Psychological capital: A positive resource for combating employee stress and turnover. Human Resource Management, 48(5), 677-693.

Avey, J. B., Luthans, F., Youssef, C. M. (2010). The additive value of positive psychological capital in predicting work attitudes and behaviors. Journal of Management, 36(2), 430-452.

Avey, J. B., Patera, J. L., West, B. J. (2006). The implications of positive psychological capital on employee absenteeism. Journal of Leadership \& Organizational Studies, 13(2), 42-60.

Avey, J. B., Wernsing, T. S., Luthans, F. (2008). Can positive employees help positive organizational change? Impact of psychological capital and emotions on relevant attitudes and behaviors. The Journal of Applied Behavioral Science, 44(1), 48-70.

Bandura, A. (1986). Fearful expectations and avoidant actions as coeffects of perceived self-inefficacy. American Psychologist, 41(12), 1389-1391.
Bandura, A., Locke, E. A. (2003). Negative self-efficacy and goal effects revisited. Journal of Applied Psycho$\log y, 88(1), 66-87$.

Barron, F., Harrington, D. M. (1981). Creativity, intelligence, and personality. Annual Review of Psycho$\log y, 32(1), 439-476$.

Battal, F. (2013). Psikolojik Sermaye, Dönüşümcü Liderlik ve Çalışanların Yaratıcılı̆̆ı Arasındaki İlişki. Unpublished Master Dissertation, Gümüşhane University, Social Sciences Institute, Department of Business Administration, Gümüşhane.

Bratnicka, K. (2013). Organizational Creativity. Unpublished Doctorate Dissertation, University of Economics, Faculty of Economics, Poland.

Carmeli, A., Meitar, R., Weisberg, J. (2006). Selfleadership skills and innovative behavior at work. International Journal of Manpower, 27(1), 75-90.

Ceylan, A., Savi, F.Z. (2003). Örgütsel yaratıcllğa etki eden faktörler üzerine bir araştırma. Istanbul University Faculty of Political Sciences Journal, 29, 151-175.

Choi, J. N. (2004). Individual and contextual predictors of creative performance: The mediating role of psychological processes. Creativity Research Journal,16(2-3), 187-199.

Cohen, H. (1981). On the modeling of creative behavior. Rand Corporation.

Çokluk, Ö. B., Şekercioğlu, G., Büyüköztürk, Ş. (2010). Sosyal bilimler için çok değişkenli istatistik, SPSS ve LISREL Uygulamalar, Ankara: Pegem Akademi.

Coutu, D. L. (2002). How resilience works. Harvard Business Review, 80(5), 46-56.

Cropley, A. J. (1999). Definitions of creativity. Encyclopedia of creativity, 1, 511-524.

Deci, E. L., Ryan, R. M. (2000). The support of autonomy and the control of behavior. Higgins, E. Tory (Ed); Kruglanski, Arie W. (Ed), (2000). Motivational science: Social and personality perspectives. Key reading in social psychology., (pp. 128-145). New York, NY, US: Psychology Press. 
Deci, E. L., Connell, J. P., \& Ryan, R. M. (1989). Selfdetermination in a work organization. Journal of Applied Psychology, 74(4), 580.

DiLiello, T. C., Houghton, J. D. (2006). Maximizing organizational leadership capacity for the future: Toward a model of self-leadership, innovation and creativity. Journal of Managerial Psychology, 21(4), 319-337.

Eren, E., Gündüz, H. (2002). The Effects Of Organizational, Management. Work Group and Task Motivations on Organizational Creativity, 11, 532-539.

Eren, E., Hülya Gündüz, Ç. (2002). Örgüt yaratıcıllğı ve verimliliğinin sağlanmasında örgüt ikliminin rolü. 10. Management and Organization Conference Proceedings, 1-10.

Erkuş, A., Afacan Fındıklı, M. (2013). Psikolojik sermayenin iş tatmini, iş performansı ve işten ayrılma niyeti üzerindeki etkisine yönelik bir araştırma. Journal of the School of Business Administration, Istanbul University, 42(2), 302-318.

Gabora, L. (2002). Cognitive mechanisms underlying the creative process. In Proceedings of the 4th conference on Creativity \& cognition (pp. 126-133). ACM.

Gist, M. E., Mitchell, T. R. (1992). Self-efficacy: A theoretical analysis of its determinants and malleability. Academy of Management Review, 17(2), 183211.

Gong, Y., Huang, J. C., Farh, J. L. (2009). Employee learning orientation, transformational leadership, and employee creativity: The mediating role of employee creative self-efficacy. Academy of Management Journal, 52(4), 765-778.

Gumusluoglu, L. Ilsev, A. (2007). Transformational leadership, creativity, and organizational innovation. Journal of Business Research, 62 (4), 461-473.

Kwang, N. A., \& Rodrigues, D. (2002). A Big-Five Personality profile of the adaptor and innovator. The Journal of Creative Behavior, 36(4), 254-268.
Gumusluoglu, L., Ilsev, A. (2009). Transformational leadership, creativity, and organizational innovation. Journal of Business Research, 62(4), 461-473.

Gupta, V. Singh, S. (2014) Psychological capital as a mediator of the relationship between leadership and creative performance behaviors: empirical evidence from the Indian R\&D sector. The International Journal of Human Resource Management, 25 (10), 1373-1394.

Hammond, M.M., Neff, N.L., Farr, J.L., Schwall, A.R., Zhao, X. (2011). Predictors of individual level innovation at work: A meta-analysis. The Psychology of Aesthetics, Creativity, and the Arts, 5, 90-105.

Hsu, M.L., Hou, S.T., Fan, H. L. (2011). Creative self-efficacy and innovative behavior in a service setting: Optimism as a moderator. The Journal of Creative Behavior, 45(4), 258-272.

Isen, A. M., Daubman, K. A., Nowicki, G. P. (1987). Positive Affect Facilitates Creative Problem Solving. Journal of Personality and Social Psychology, 1122-1131.

Islamoglu, G. (2010). Kurumlarda İilik de Var. Ankara: Nobel Press.

Jung, C. G. (2001). Modern Man in Search of a Soul. Psychology Press.

Kahai, S. S., Sosik, J. J., \& Avolio, B. J. (2003). Effects of leadership style, anonymity, and rewards on creativity-relevant processes and outcomes in an electronic meeting system context. The Leadership Quarterly, 14(4), 499-524.

Kaufman, J. C., Cole, J. C., Baer, J. (2009). The Construct of Creativity: Structural Model for Self-Reported Creativity Ratings. The Journal of Creative Behavior, 43(2), 119-134.

Kirkman, B. L., Lowe, K. B., Young, D. P. (1999). Highperformance work organizations: Definitions, practices, and an annotated bibliography. Center for Creative Leadership. CCL Sourcebooks, No.342. 
Kor, Y. Y., Mahoney, J. T. (2000). Penrose’s resource-based approach: The process and product of research creativity. Journal of Management Studies, 37(1), 109-139.

Larson, M., Luthans, F. (2006). Potential added value of psychological capital in predicting work attitudes. Journal of Leadership \& Organizational Studies, 13(2), 75-92.

Luthans, F. (2002a). The need for and meaning of positive organizational behavior. Journal of Organizational Behavior, 23, 695-706.

Luthans, F. (2002b). Positive organizational behavior: Developing and managing psychological strengths. Academy of Management Executive, 16(1), 57-72.

Luthans, F., Youssef, C. M. (2007). Emerging positive organizational behavior. Journal of Management, 33(3), 321-349.

Luthans, F., Avolio, B. J., Avey, J. B., Norman, S. M. (2007). Positive psychological capital: Measurement and relationship with performance and satisfaction. Personnel Psychology, 60(3), 541-572.

Luthans, F., Luthans, K. W., Luthans, B. C. (2004). Positive psychological capital: Beyond human and social capital. Business Horizons, 47(1), 45-50.

Luthans, F., Norman, S.M., Avolio, B.J. Avey, J.B. (2008). The mediating role of psychological capital in the supportive organizational climate-employee performance relationship. Journal of Organizational Behavior, 29, 219-238.

Luthans, F., Youssef, C. M., Avolio, B. J. (2007). Psychological Capital. New York.

Masten, A. S., Reed, M. G. J.(2002). Resilience in development. Handbook of Positive Psychology, 74-88.

Mishra, L. K., Singh, A. P. (2010). Creative behavior questionnaire: Assessing the ability of managers to produce creative ideas. Journal of the Indian Academy of Applied Psychology, 36(1), 115-121.
Mishra, P., Bhatnagar, J., Gupta, R. (2013). Role of psychological capital in the relationship between work-to-family enrichment, family-to-work enrichment and innovative work behavior. 3rd Biennial Conference of the Indian Academy of Management (IAM), 2013 held at IIMA during 12-14 December, 2013, Full paper is derived from http://vslir.iimahd.ernet.in:8080/xmlui/handle/123456789/11622.

Moores, T. T., \& Chang, J. C. J. (2009). Self-efficacy, overconfidence, and the negative effect on subsequent performance: A field study. Information \& Management, 46(2), 69-76.

Mostafa, M. (2005). Factors affecting organizational creativity and innovativeness in Egyptian business organizations: An empirical investigation. Journal of Management Development, 24(1), 7-33.

Mumford, M. D. (2000). Managing creative people: strategies and tactics for innovation. Human Resource Management Review, 10(3), 313-351.

Nielsen, K., Yarker, J., Randall, R., Munir, F. (2009). The mediating effects of team and self-efficacy on the relationship between transformational leadership, and job satisfaction and psychological well-being in healthcare professionals: a cross-sectional questionnaire survey. International journal of nursing studies,46 (9), 1236-1244.

Oldham, G. R., Cummings, A. (1996). Employee creativity: Personal and contextual factors at work. Academy of Management Journal, 39(3), 607-634.

Perry-Smith, J. E., Shalley, C. E. (2003). The social side of creativity: A static and dynamic social network perspective. Academy of Management Review, 28(1), 89-106.

Peterson, C. (2000). The future of optimism. American Psychologist, 55 (1), 44.

Peterson, S. J., Walumbwa, F. O., Byron, K. Myrowitz (2009). CEO positive psychological trait, transformational leadership, and firm performance in high-technology start-up and established firms. Journal of Management, 35, 348-368. 
Polatçı, S. (2014). Psikolojik sermayenin görev ve bağlamsal performans üzerindeki etkileri: Polis teşkilatında bir araştırma. Ege Academic Review,14(1), 1-22.

Redmond, M. R., Mumford, M. D., Teach, R. (1993). Putting creativity to work: Effects of leader behavior on subordinate creativity. Organizational Behavior and Human Decision Processes, 55(1), 120-151.

Rego, A., Machado, F., Leal, S., Cunha, M. P. E. (2009). Are hopeful employees more creative? An empirical study. Creativity Research Journal, 21(2-3), 223231.

Rego, A., Sousa, F., Marques, C., Cunha, M. P. E. (2012). Optimism predicting employees' creativity: The mediating role of positive affect and the positivity ratio. European Journal of Work and Organizational Psychology, 21(2), 244-270.

Schabracq, M. J., Winnubst, J. A., Cooper, C. L. (Eds.). (2003). The handbook of work and health psycho$\log y$. John Wiley \& Sons.

Scott, S. G., Bruce, R. A. (1994). Determinants of innovative behavior: A path model of individual innovation in the workplace. Academy of Management Journal, 37(3), 580-607.

Seligman, M. (1998). What is the good life. APA Monitor, 29(10), 1-22.

Seligman, M. E. (2002). Authentic happiness: Using the new positive psychology to realize your potential for lasting fulfillment. Simon and Schuster.

Seligman, M. E., Csikszentmihalyi, M. (2000). Positive psychology: An introduction. American Psychological Association, 55(1), 1-25.

Şencan, H. (2005). Sosyal ve Davranışsal Ölçümlerde Güvenilirlik ve Geçerlilik. Ankara: Seçkin Press.

Shalley, C. E., Gilson, L. L. (2004). What leaders need to know: A review of social and contextual factors that can foster or hinder creativity. The Leadership Quarterly, 15(1), 33-53.
Shalley, C. E., Perry-Smith, J. E. (2001). Effects of social-psychological factors on creative performance: The role of informational and controlling expected evaluation and modeling experience. Organizational Behavior and Human Decision Processes, 84(1), $1-22$.

Shalley, C. E., Gilson, L. L., Blum, T. C. (2000). Matching creativity requirements and the work environment: Effects on satisfaction and intentions to leave. Academy of Management Journal, 43(2), 215223.

Shalley, C. E., Zhou, J., Oldham, G. R. (2004). The effects of personal and contextual characteristics on creativity: Where should we go from here?.Journal of Management, 30(6), 933-958.

Simonton, D. K. (2000). Creativity: Cognitive, personal, developmental, and social aspects. American Psychologist, 55(1), 151.

Sipahi, B., Yurtkoru, E.S., Çinko, M. (2012). Sosyal Bilimlerde SPSS ile Veri Analizi(SPSS Data Analysis for Social Sciences). İstanbul: Beta Publishing.

Snyder, C. R. (1994). The psychology of hope: You can get there from here. Simon and Schuster.

Snyder, C. R. (2000). The past and possible futures of hope. Journal of Social and Clinical Psycho$\log y, 19(1), 11-28$.

Snyder, C. R., Irving, L. M., Anderson, J. R. (1991). Hope and health. Forsyth, Donelson R. (Ed), (1991). Handbook of social and clinical psychology: The health perspective. Pergamon general psychology series, Vol. 162., (pp. 285-305). Elmsford, NY, US: Pergamon Press.

Stajkovic, A. D. (2003). Introducing positive psychology to work motivation: Development of a core confidence model. In Academy of Management national meeting, Seattle, Washington.

Stajkovic, A. D., Luthans, F. (1998). Self-efficacy and work-related performance: A meta-analysis. Psychological bulletin, 124(2), 220-240. 
Staw, B. M. (1990). An evolutionary approach to creativity and innovation. West, Michael A. (Ed); Farr, James L. (Ed), (1990). Innovation and creativity at work: Psychological and organizational strategies. (pp. 287-308). Oxford, England: John Wiley \& Sons.

Sternberg, R. J. (1985). Implicit theories of intelligence, creativity, and wisdom.Journal of Personality and Social Psychology, 49(3), 607.

Sternberg, R. J. (2006). The nature of creativity. Creativity Research Journal, 18(1), 87-98.

Sternberg, R. J., Lubart, T. I. (1991). An investment theory of creativity and its development. Human Development, 34(1), 1-31.

Sutter, R. (2008). The Existence of Positive Psychological Environments and Their Impact on Regional Entrepreneurship. The Journal of Regional Analysis and Policy, 38(3), 279-292.

Sweetman, D., Luthans, F., Avey, J. B., \& Luthans, B. C. (2011). Relationship between positive psychological capital and creative performance. Canadian Journal of Administrative Sciences, 28(1), 4-13.

Tang, Y. T., Chang, C. H. (2010). Impact of role ambiguity and role conflict on employee creativity. African Journal of Business Management, 4(6), 869-881.

Tekin, B. (2008). The relationship between work environment and creativity "an application in white-goods sector". Unpublished Master Dissertation, Marmara University, Social Sciences Institute, Department of Business Management, Istanbul.

Tierney, P., Farmer, S. M. (2002). Creative self-efficacy: Its potential antecedents and relationship to creative performance. Academy of Management Journal, 45(6), 1137-1148.

Tierney, P., Farmer, S. M., Graen, G. B. (1999). An examination of leadership and employee creativity: The relevance of traits and relationships. Personnel Psychology, 52(3), 591-620.
Tugade, M. M., Fredrickson, B. L., Feldman Barrett, L. (2004). Psychological resilience and positive emotional granularity: Examining the benefits of positive emotions on coping and health. Journal of personality, 72(6), 1161-1190.

Vancouver, J. B., Thompson, C. M., Tischner, E. C., \& Putka, D. J. (2002). Two studies examining the negative effect of self-efficacy on performance. Journal of Applied Psychology, 87(3), 506-516.

Wong, S., Pang, L. (2003). Motivators to creativity in the hotel industry-perspectives of managers and supervisors. Tourism Management, 24(5), 551-559.

Woodman, R. W., Sawyer, J. E., Griffin, R. W. (1993). Toward a theory of organizational creativity. Academy of Management Review, 18(2), 293-321.

Yahyagil, M. Y. (2005). The organizational creativity: A empirical exploration and a guide for practitioners. İstanbul University Business Administration Faculty Journal, 34 (2), 81-110.

Zajacova, A., Lynch, S. M., Espenshade, T. J. (2005). Self-efficacy, stress, and academic success in college. Research in Higher Education, 46(6), 677-706.

Zhou, J. (2003). When the presence of creative coworkers is related to creativity: role of supervisor close monitoring, developmental feedback, and creative personality. Journal of Applied Psychology, 88(3), 398-413.

Zhou, J., George, J. M. (2001). When job dissatisfaction leads to creativity: Encouraging the expression of voice. Academy of Management journal, 44(4), 682-696.

Zhou, J., George, J. M. (2003). Awakening employee creativity: The role of leader emotional intelligence. The Leadership Quarterly, 14(4), 545-568. 